\title{
PENGARUH AKSESIBILITAS LINGKUNGAN KERJA TERHADAP KINERJA KARYAWAN BPR SYARIAH AL- MADINAH KOTA TASIKMALAYA
}

\author{
Syamsudin Arnasik ${ }^{1}$, Edi Fitriana Afriza ${ }^{2}$ \\ Jurusan Pendidikan Ekonomi, Fakultas FKIP, Universitas Siliwangi \\ 11 syamsudinarnasik@unsil.ac.id, 22edifitriana@unsil.ac.id
}

JURNAL

MANAJEMEN

INDONESIA

Vol.17 No.3

Abstrak

Lingkungan kerja yang kurang representatif bagi karyawan dipandang para ahli sebagai hal yang tidak efektif dan efisien. Tidak representatifnya lingkungan kerja menjadi ancaman utama yang mengakibatkan menurunnya kinerja karyawan dan menyebabkan ketidakberhasilan dalam pencapaian kerja di perusahaan. Munculnya permasalahan tersebut menjadi dasar keterkaitan bahwa lingkungan kerja dapat memberikan stimulus pada kinerja karyawan. Penelitian ini merupakan penelitian explanatory research dengan metode survei kepada 22 responden. Teknik analisis data yang dipergunakan adalah analisis statistik inferensial, yang merupakan analisis regresi linier berganda dengan menggunakan program SPSS 20.0. Dari hasil uji parsial dinyatakan bahwa aksesibilitas lingkungan kerja fisik tidak berpengaruh signifikan pada kinerja karyawan, sedangkan lingkungan kerja non-fisik menginterprestasikan sebaliknya. Secara simultan terdapat pengaruh signifikan aksesibilitas lingkungan kerja pada kinerja karyawan. Sejatinya penerapan aksesibilitas lingkungan kerja dapat direalisasikan secara holistik sehingga akan meningkatkan kinerja karyawan BPR Syariah Al-Madinah Kota Tasikmalaya.

Kata kunci: Aksesibilitas, Lingkungan Kerja, Kinerja, Karyawan

\begin{abstract}
Distressing a workplace atmosphere may generate ineffective and inefficient working performance for the employees according to a number of experts. This potentially triggers predominant threats to the companies, such as decreasing employees' working performances and failures of attaining institutional goals. The emergence of such threats become an underlying interconnection that workplace can stimulate the employees' working performances. Methodologically, this study adopted explanatory research with survey as the research design and quantitative research as the research approach. Research instruments were distributed to 22 participants. In analyzing the data, this study utilized inferential statistics in which multiple linear regression analysis supported by SPSS 20.0 for Windows as the data analysis tool. Based on the partial test analysis, accessibility of physical work environments did not significantly influence the employees' working performances. On the other hand, the non-physical working environments were interpreted inversely, namely there was a simultaneous significant accessibility of workplace to the employees' working performances. Ideally, the implementation of workplace can be realized holistically so that it may be able to raise the working performances, particularly to enhance the BPR Syariah Al-Madinah Kota Tasikmalaya.
\end{abstract}

Keywords: Accessibility, Work environments, Employees, Working Performance

\section{Pendahuluan}

Peningkatan kualitas Sumber Daya Manusia (SDM) adalah suatu hal yang penting dalam pengembangan kinerja perusahaan. Namun, banyak perusahaan yang mengabaikan hal ini yang hanya mengandalkan seiring berjalannya waktu ketika para karyawan dapat meningkatkan kinerja yang seadanya. Menurut Siagian (2002:286), kinerja karyawan dipengaruhi oleh beberapa faktor yaitu: gaji, lingkungan kerja, budaya organisasi, kepemimpinan dan motivasi

PENGARUH AKSESIBILITAS LINGKUNGAN KERJA... 
kerja, disiplin kerja, kepuasan kerja, komunikasi, dan faktor-faktor lainnya. Sedangkan menurut De Cenzo dan Robbins (1996:11), "Environmental influences are those factors outside the organization that directly affect HRM operation".

\section{JURNAL}

MANAJEMEN

INDONESIA

\section{Vol.17 No.3}

Desember 2017
Hasil penelitian Ganapathi dan Prasad (2008) mengemukakan bahwa;

"Working environment plays a crucial role in enhancing the performance of an individual and the organization as a whole. In poor working environment, it becomes particularly challenging to maintain a productive and satisfying work life and in turn threatens the work success. Article concludes with a number of counter measures to be followed by the organization to create a conducive working environment backed up by genuine efforts to motivate the human resources"

Berdasarkan De Cenzo dan Robbins (1996:11), lingkungan kerja mempunyai peran penting dalam meningkatkan kinerja individu dan organisasi secara keseluruhan. Dalam lingkungan kerja yang buruk, menjadi tantangan tersendiri untuk mempertahankan kegiatan kerja yang produktif dan memuaskan yang pada gilirannya akan mengancam tercapainya keberhasilan kerja. Langkah yang berlawanan diambil untuk diikuti oleh organisasi dalam menciptakan lingkungan kerja yang kondusif dan didukung oleh upaya tulus untuk memotivasi karyawan.

BPR Syariah Al-Madinah dalam hal ini merupakan perusahaan perbankan Badan Usaha Milik Daerah (BUMD) yang berupaya menciptakan lingkungan kerja yang representatif bagi karyawan untuk meningkatkan gairah dalam bekerja, sehingga karyawan dalam melakukan pekerjaanya berupaya mencapai target yang telah ditetapkan perusahaan. Dengan upaya tersebut perusahaan menaruh harapan untuk perubahan dan peningkatan kinerja karyawan.

Lingkungan kerja yang representatif mengacu pada Keputusan Menteri Kesehatan Republik Indonesia Nomor 1405/ MENKES/ SK/ XI/ 2002 tentang Persyaratan kesehatan lingkungan kerja perkantoran dan industri yang meliputi persyaratan air, udara, limbah, pencahayaan, kebisingan, getaran, radiasi, vektor penyakit, persyaratan kesehatan lokasi, ruang dan bangunan, toilet dan instalasi. Persyaratan kesehatan lingkungan kerja dalam keputusan ini diberlakukan baik terhadap kantor yang berdiri sendiri maupun yang berkelompok.

Berdasarkan penelitian dari Becker (1985) diperoleh hasil bahwa;

"Quality of Work Environment (QWE) is viewed as one facet of the Quality of Worklife $(Q W L)$ movement. Attention is thus paid not only to direct health effects of adverse environmental conditions, but also to how the physical conditions of work contribute to a sense of competence and to job satisfaction and performance."

Berdasarkan penjelasan diatas menyatakan bahwa QWE dipandang sebagai salah satu aspek dari gerakan QWL. Oleh karena itu, perhatian pada lingkungan kerja diberikan bukan hanya untuk efek kesehatan langsung dari kondisi lingkungan yang buruk, tetapi juga bagaimana kondisi fisik kerja berkontribusi pada kompetensi dan kepuasan kerja dan kinerja.

Dilihat dari kondisi di Kantor BPR Syariah Al-Madinah, lingkungan kerja di tempat tersebut memiliki kendala dalam mengoptimalkan lingkungan kerja yang kondusif, dimana lokasi kantor tersebut berdekatan dengan jalan raya yang banyak dilalui oleh kendaraan bermotor yang memungkinkan terjadinya kebisingan. Sedangkan dilihat dari fasilitas parkir bagi karyawan dinilai tidak memadai bahkan karyawan yang memiliki kendaraan roda empat tidak sedikit yang menggunakan jalan raya untuk parker. Selain itu, kurangnya pencahayaan dari sinar matahari yang berdampak negatif bagi kesehatan para karyawannya. Interaksi dan komunikasi yang dinilai kurang intensif antara atasan dan bawahan dimana kondisi atasan dan bawahan dalam bekerja masih terasa kaku dan adanya jurang pembatas bagi karyawan senior dan junior mengakibatkan lingkungan kerja yang kurang representatif bagi karyawan.

Lingkungan kerja diidentifikasi dalam dua bagian diantaranya lingkungan kerja fisik yang bersifat tangible dan lingkungan kerja non-fisik (intangible). Pada dasarnya, lingkungan kerja memikiki peranan penting dalam menunjang rasa aman, nyaman dan menyehatkan bagi 
karyawan dalam melakukan pekerjaan dan meningkatkan kinerjanya. Setiap individu dan kelompok yang bekerja di perusahaan memberikan reaksi terhadap dampak psikologi yang ditimbulkan dari lingkungan kerja fisik maupun non-fisik. Organisasi perusahaan yang memfokuskan pada pemenuhan akses karyawan dalam lingkungan kerja memberikan dampak secara langsung pada percepatan pencapaian tujuan, hal ini dikarenakan kondisi lingkungan yang memadai dapat memacu karyawan bekerja lebih baik dan mengoptimalkan penyelesaian pekerjaan tepat pada waktunya. "Organizations and their HR departements are open system and are affected by the environment in wich they operate" (Werther and Davis, 1996:30)

\section{Kajian Literatur}

\subsection{Kinerja Karyawan.}

Perkembangan usaha dan organisasi perusahaan sangatlah bergantung pada kinerja karyawan yang ada di perusahaan. Dengan pengelolaan karyawan secara profesional diharapkan karyawan dapat bekerja secara produktif, akan tetapi dalam suatu perusahaan sudah menjadi permasalahan yang umum jika kinerja karyawan menurun drastis dimungkinkan adanya karena kondisi fisik dan psikologis yang diakibatkan dari lingkungan tempat kerja yang tidak sehat, kurang memberi rasa aman dan nyaman. Performance diterjemahkan menjadi kinerja, juga berarti prestasi kerja, pelaksanaan kerja, pencapaian kerja atau hasil kerja/unjuk kerja/penampilan kerja (LAN, 1992:3).

Sedangkan Smith (1982:393) menyatakan bahwa performance atau kinerja adalah: “...... output drive from processes, human or otherwise". Jadi dikatakannya bahwa kinerja merupakan hasil atau keluaran dari suatu proses. Berdasarkan pernyataan para ahli di atas dapat disimpulkan bahwa kinerja merupakan pencapaian dan hasil kerja baik secara kualitas dan kuantitas yang dilakukan karyawan melalui suatu proses pekerjaan dan tanggung jawabnya.

\subsection{Lingkungan Kerja.}

Menurut Simanjuntak (2003:39) lingkungan kerja dapat diartikan sebagai keseluruhan alat perkakas yang dihadapi, lingkungan sekitarnya dimana seorang bekerja, metode kerjanya, sebagai pengaruh kerjanya baik sebagai perorangan maupun sebagai kelompok. Sedangkan menurut Sutrisno (2010:118) Lingkungan kerja adalah keseluruhan sarana dan prasarana kerja yang ada di sekitar karyawan yang sedang melakukan pekerjaan yang dapat mempengaruhi pelaksanaan pekerjaan. Dari berbagai pendapat di atas, dapat disimpulkan bahwa lingkungan kerja merupakan segala sesuatu yang berbentuk fisik serta non fisik dan berada disekitar karyawan, berkaitan dalam menunjang pekerjaan sehari-harinya. Lingkungan kerja merupakan penciptaan jati diri perusahaan, sebuah perusahaan yang mempunyai lingkungan kerja yang kondusif dapat menumbuhkan gairah kerja dan percepatan kerja karyawan.

\subsection{Hubungan Lingkungan Kerja dan Kinerja Karyawan.}

Menurut Mangkunegara (2004:68), lingkungan kerja mempunyai hubungan yang sangat erat terhadap kinerja karyawan, motif berprestasi yang perlu dimiliki oleh karyawan harus ditumbuhkan dari dalam diri sendiri dan dari lingkungan kerja, karena motif berprestasi yang ditumbuhkan dari dalam diri sendiri akan membentuk suatu kekuatan diri dan jika situasi lingkungan kerja turut menunjang maka pencapaian kinerja akan lebih mudah.

Selain itu Nitisemito (2002:171-173), mengungkapkan hendaknya perusahaan dapat mencerminkan kondisi lingkungan kerja yang dapat mendukung kinerja karyawan dan kerja sama antar tingkat atasan, bawahan maupun yang memiliki status jabatan yang sama di perusahaan. Dari pernyataan para ahli diatas maka dapat disimpulkan bahwa menciptakan kondisi lingkungan yang repersentatif bagi karyawan merupakan kewajiban dari setiap perusahaan, jika para steakholder menginginkan para karyawannya menunjukkan kinerja yang baik pada perusahaan. Karyawan perlu diberikan hak-haknya ketika dalam melakukan pekerjaan, lingkungan kerja yang menujang akan memberikan ruang bagi mereka sehingga timbal balik dari karyawan pada perusahaan berupa optimalisasi hasil pekerjaan yang sesuai standar perusahaan. 


\section{Metode Penelitian}

Penelitian ini menggunakan jenis penelitian expalanatory research dengan pendekatan kuantitatif. Explanatory research merupakan penelitian yang digunakan untuk menjelaskan hubungan kausal antara variabel-variabel melalui pengujian hipotesa yang dirumuskan atau sering kali disebut sebagai penelitian penjelas (Masri dan Effendi, 2006). Penelitian ini memiliki tingkat yang tinggi karena tidak hanya mempunyai nilai mandiri maupun membandingkan tetapi juga berfungsi untuk menjelaskan, meramalkan, dan juga mengontrol suatu gejala dengan pendekatan kuantitatif. Penulis menggunakan metode survei dengan mendatangi langsung kantor BPR Syariah Al-Madinah yang beralamat di Jalan Sutisna Senjaya No. 99 Kota Tasikmalaya dan mengumpulkan data primer serta sekunder melalui wawancara, observasi lapangan dan penyebaran kuesioner kepada karyawan. Seluruh karyawan BPR Syariah AlMadinah dijadikan populasi yaitu sebanyak 22 orang karyawan. Dikarenakan jumlah populasi kurang dari 100 responden maka teknik sampling yang digunakan merupakan teknik sampling jenuh yaitu teknik penentuan sampel bila semua anggota populasi digunakan sebagai sampel. Istilah lain sampel jenuh adalah sensus, yaitu semua anggota populasi dijadikan sampel (Sugiyono, 2010). Sampel dalam penelitian ini sama dengan jumlah populasi yaitu 22 orang karyawan BPR Syariah Al-Madinah Kota Tasikmalaya. Data penelitian terlebih dahulu melewati pengujian instrumen yang yaitu uji validitas dan realibilitas dilanjutkan dengan uji asumsi klasik yang terdiri dari uji normalitas, uji multikolinieritas, uji heterokesdastisitas dan autokorelasi. Sedangkan untuk pengujian parsial dan simultan dilakukan melalui uji f dan uji t.

\section{Uji Validitas dan Reliabilitas}

Uji validitas dan relibilitas penelitian ini dilakukan dengan membandingkan angka kritis tabel korelasi pada derajat kebebasan $(\mathrm{dk}=\mathrm{n}-2)$ dengan taraf signifikan $\alpha=5 \%$, dapat dinilai uji dua sisi pada signifikasi 0,05 terdapat jumlah data $n=22$, maka didapat $r_{\text {tabel }}$ sebesar $(0,423)$.

Kriteria pengujian :

Jika $\mathbf{r}_{\text {hitung }}>\mathrm{r}_{\text {tabel }}$, maka pernyataan tersebut valid.

Jika $\mathrm{r}_{\text {hitung }}<\mathrm{r}_{\text {tabel }}$, maka pernyataan tersebut tidak valid.

Tabel 1 merupakan hasil perhitungan uji validitas Variabel X1 (Lingkungan Kerja Fisik), X2 (Lingkungan Kerja Non Fisik), dan Y1 (Kinerja Karyawan) yang menggunakan program SPSS for Windows Versi 20:

Tabel 1. Rangkuman Hasil Uji Validitas Sumber: Data yang telah diolah (2017)

\begin{tabular}{|c|c|c|c|c|}
\hline Variabel & No. & rhitung & rtabel & Keterangan \\
\hline \multirow{4}{*}{$\begin{array}{c}\text { Lingkungan Kerja Fisik } \\
\text { (X1) }\end{array}$} & 1. & 0,332 & 0,423 & Tidak Valid \\
\cline { 2 - 5 } & 2. & 0,676 & 0,423 & Valid \\
\cline { 2 - 5 } & 3. & 0,864 & 0,423 & Valid \\
\cline { 2 - 5 } & 4. & 0,668 & 0,423 & Valid \\
\cline { 2 - 5 } & 5. & 0,832 & 0,423 & Valid \\
\cline { 2 - 5 } & 6. & 0,694 & 0,423 & Valid \\
\cline { 2 - 5 } & 7. & 0,802 & 0,423 & Valid \\
\cline { 2 - 5 } & 8. & 0,816 & 0,423 & Valid \\
\cline { 2 - 5 } & 9. & 0,839 & 0,423 & Valid \\
\cline { 2 - 5 } & 10. & 0,812 & 0,423 & Valid \\
\cline { 2 - 5 } & 11. & 0,231 & 0,423 & Tidak Valid \\
\cline { 2 - 5 } & 12. & $-0,016$ & 0,423 & Tidak Valid \\
\cline { 2 - 5 } & 13. & 0,585 & 0,423 & Valid \\
\cline { 2 - 5 } Fingkungan Kerja Non (X2) & 14. & 0,561 & 0,423 & Valid \\
\cline { 2 - 5 } & 15. & 0,820 & 0,423 & Valid \\
\cline { 2 - 5 } & & &
\end{tabular}




\begin{tabular}{|c|c|c|c|c|}
\hline Variabel & No. & rhitung & rtabel & Keterangan \\
\hline & 16. & 0,865 & 0,423 & Valid \\
\cline { 2 - 5 } & 17. & 0,773 & 0,423 & Valid \\
\cline { 2 - 5 } & 18. & 0,702 & 0,423 & Valid \\
\cline { 2 - 5 } & 19. & 0,884 & 0,423 & Valid \\
\hline \multirow{5}{*}{ Kinerja Karyawan (Y1) } & 20. & 0,927 & 0,423 & Valid \\
\cline { 2 - 5 } & 21. & 0,797 & 0,423 & Valid \\
\cline { 2 - 5 } & 22. & 0,908 & 0,423 & Valid \\
\cline { 2 - 5 } & 23. & 0,927 & 0,423 & Valid \\
\cline { 2 - 5 } & 24. & 0,913 & 0,423 & Valid \\
\cline { 2 - 5 } & 25. & 0,845 & 0,423 & Valid \\
\cline { 2 - 5 } & 26. & 0,512 & 0,423 & Valid \\
\cline { 2 - 5 } & 27. & 0,154 & 0,423 & Tidak Valid \\
\cline { 2 - 5 } & 28. & 0,792 & 0,423 & Valid \\
\cline { 2 - 5 } & 29. & 0,278 & 0,423 & Tidak Valid \\
\cline { 2 - 5 } & 30. & 0,946 & 0,423 & Valid \\
\hline
\end{tabular}

JURNAL

MANAJEMEN

INDONESIA

Vol.17 No.3

Desember 2017

Berdasarkan tabel 1, uji validitas butir pertanyaan masing-masing variabel dapat diketahui bahwa dari 30 butir pertanyaan yang diujikan, terdapat 25 butir pertanyaan yang menunjukaan hasil valid (sahih). Sedangkan 5 butir pertanyaan dinyatakan gugur yaitu 3 butir pertanyaan mengenai lingkungan kerja dan 2 butir pertanyaan mengenai kinerja karyawan. Dengan demikian 5 butir pertanyaan yang tidak valid tidak digunakan lebih lanjut dalam penelitian ini sehingga hanya 25 butir pernyataan yang dapat dilanjutkan untuk dihitung angka reliabilitas instrumennya.

\section{Uji Realibilitas Instrumen}

Metode uji realibilitas yang digunakan pada penelitian ini adalah Cronbach's Alpha. Menurut Uma Sekaran (dalam Priyatno, 2013:30) pengambilan keputusan uji reliabilitas sebagai berikut:

\begin{tabular}{|c|c|}
\hline Nilai Koefisien & Kategori \\
\hline $\mathrm{r} \geq 0,8$ & Sangat Kuat \\
\hline $0,6 \leq \mathrm{r}<0,8$ & Kuat \\
\hline $0,4 \leq \mathrm{r}<0,6$ & Sedang \\
\hline $\mathrm{r}<0,4$ & Kurang \\
\hline
\end{tabular}

Tabel 2. Klasifikasi

Koefisien

Reliabilitas

Sumber: (Priyatno,

Adapun hasil analisis uji reliabilitas yang menggunakan program SPSS for Windows Versi 20 dapat dilihat pada tabel berikut:

\begin{tabular}{|c|c|c|c|}
\hline Variabel & Nilai Alpha & Status & Kategori \\
\hline Lingkungan Kerja Fisik & 0,889 & Reliabel & Sangat Kuat \\
\hline Lingkungan Kerja Non Fisik & 0,775 & Reliabel & Kuat \\
\hline Kinerja Karyawan & 0,890 & Reliabel & Sangat Kuat \\
\hline
\end{tabular}

Tabel 3.

Rangkuman Hasil

Uji Realibilitas

Sumber: Data yang telah diolah (2017) 
Berdasarkan hasil uji realibilitas dalam tabel 3 menunjukkan bahwa nilai alpha untuk variabel independen sebesar 0,889 (X1) berkategori sangat kuat dan 0,775 (X2) berkategori kuat, sedangkan nilai alpha yang diperoleh variabel dependen sebesar 0,890 (Y1) berkategori sangat kuat. Jadi secara keseluruhan butir-butir pertanyaan yang ada dalam masing-masing variabel adalah reliabel.

\section{MANAJEMEN \\ INDONESIA}

\section{Vol.17 No.3}

Desember 2017
Tabel 4. Hasil Uji

Normalitas

Sumber: Data yang telah diolah (2017)

\section{$4 \quad$ Hasil dan Pembahasan}

Penelitian ini menggunakan analisis regresi linear berganda untuk menguji hipotesis penelitian sehingga perlu terlebih dahulu untuk melakukan uji asumsi klasik agar data yang didapatkan dapat diolah lebih lanjut. Uji asumsi klasik yang telah dilakukan dalam penelitian ini meliputi uji normalitas, uji heterokedastisitas, dan uji multikolinieritas.

\subsection{Uji Asumsi Klasik}

\section{Uji Normalitas}

Uji normalitas dilakukan untuk menilai sebaran data pada sebuah kelompok data atau variabel, apakah terdistribusi normal atau sebaliknya. Penelitian ini menggunakan uji Kolmogorow Smirnov untuk menguji distribusi normal data yang akan diolah.

Kaidah pengujian uji normalitas adalah sebagai berikut:

$\mathrm{H}_{0}$ : Data berdistribusi normal;

$\mathrm{H}_{1}$ : Data tidak berdistribusi normal;

Kriteria uji hipotesis, jika sig $<0,05 \mathrm{H}_{0}$ ditolak, $\mathrm{H}_{1}$ diterima; jika sig $>0,05 \mathrm{H}_{0}$ diterima, $\mathrm{H}_{1}$ ditolak. Atau dengan menggunakan ketentuan sebagai berikut, jika nilai sig $<0,05$ maka data tidak berdistribusi normal; jika nilai sig $>0,05$ maka data berdistribusi normal. Adapun hasil analisis uji normalitas yang menggunakan program SPSS for Windows Versi 20 dapat dilihat pada tabel berikut:

\begin{tabular}{|c|c|}
\hline & Unstandardized Residual \\
\hline Kolmogorov-Smirnov Z & .824 \\
Asymp. Sig. (2-tailed) & \\
\hline
\end{tabular}

Berdasarkan hasil uji normalitas dengan menggunakan uji Kolmogorow Smirnov pada tabel 4 menunjukkan bahwa nilai sig sebesar 0,824 lebih besar dari 0,05. Jadi dapat disimpulkan bahwa data yang diuji termasuk data yang berdistribusi normal.

\section{Uji Multikolinieritas}

Untuk mendeteksi adanya multikolinieritas, maka dasar pengambilan keputusan pada uji multikolinieritas dapat dilakukan dengan dua cara yakni:

Jika nilai tolerance $>0,10$ maka tidak terjadi multikolinieritas, dan jika nilai tolerance < 0,10 maka terjadi multikolinieritas. Sedangkan Jika nilai VIF $<10,00$ maka tidak terjadi multikolinieritas dan jika nilai VIF > 10,00 maka terjadi multikolinieritas pada data tersebut. Adapun hasil analisis uji multikolinieritas yang menggunakan program SPSS for Windows Versi 20 dapat dilihat pada tabel berikut: 


\begin{tabular}{|c|c|c|c|}
\hline \multirow{2}{*}{ Model } & \multicolumn{2}{c|}{ Collinearity Statistics } \\
\cline { 3 - 4 } \multicolumn{2}{|c|}{} & Tolerance & VIF \\
\hline 1 & (Constant) & & \\
\hline & L. Kerja Fisik & .990 & 1.010 \\
\hline & L. Kerja Non Fisik & .990 & 1.010 \\
\hline
\end{tabular}

Berdasarkan hasil uji multikolinieritas pada tabel 5 terdapat nilai tolerance lingkungan kerja baik fisik dan non-fisik diperoleh sebesar 0,990 >0,10. Sementara itu, hasil nilai VIF pada lingkungan kerja diperoleh nilai sebesar 1,010 < 10,00 sehingga dapat disimpulkan tidak terdapat gejala multikolinieritas sehingga penelitian ini dapat menggunakan analisis regresi.

\section{Uji Heteroskedastisitas}

Untuk mendeteksi adanya ketidaksamaan varian dari residual satu pengamatan ke pengamatan yang lain, maka dasar pengambilan keputusan pada uji heteroskedastisitas terpenuhi jika nilai signifikasi lebih besar dari 0,05 maka tidak terjadi heteroskedastisitas dan jika nilai signifikasi lebih kecil dari 0,05 maka terjadi heteroskedastisitas pada data tersebut. Adapun hasil analisis uji heteroskedastisitas yang menggunakan program SPSS for Windows Versi 20 dapat dilihat pada tabel berikut:

\begin{tabular}{|c|c|c|}
\hline \multicolumn{2}{|c|}{ Model } & Sig. \\
\hline \multirow{3}{*}{1} & (Constant) & .222 \\
\cline { 2 - 3 } & L. Kerja Fisik & .679 \\
\cline { 2 - 3 } & L. Kerja Non Fisik & .019 \\
\hline
\end{tabular}

Berdasarkan uji heteroskedastisitas pada tabel 6 dapat diketahui nilai signifikasi variabel Lingkungan Kerja Fisik (X1) sebesar 0,679 lebih besar dari 0,05, artinya tidak terjadi heteroskedastisitas pada variabel Lingkungan Kerja Fisik (X1). Sedangkan nilai signifikasi variabel Lingkungan Kerja Non Fisik (X2) sebesar 0,019 lebih kecil dari 0,05, artinya terjadi heteroskedastisitas pada variabel Lingkungan Kerja Non Fisik (X2).

\section{Uji Autokorelasi}

Uji autokorelasi bertujuan menguji apakah dalam model regresi linier ada korelasi antara kesalahan pengganggu pada periode $\mathrm{t}$ dengan kesalahan pengganggu pada periode $\mathrm{t}-1$ (sebelumnya). Jika terjadi korelasi, maka dinamakan ada problem autokorelasi (Ghozali, 2011). Autokorelasi muncul karena observasi yang beruntun sepanjang waktu berkaitan satu dengan yang lainnya. Munculnya kesalahan tersebut menjadi pengganggu tidak bebas sehingga penulis tidak meneliti lebih lanjut. Dari keempat uji asumsi, peneliti hanya menggunakan tiga uji karena data dalam penelitian yang diperoleh tidak bersifat time series sehingga tidak menggunakan uji asumsi klasik autokorelasi.
JURNAL

MANAJEMEN

INDONESIA

Vol.17 No.3

Desember 2017

Tabel 5. Hasil

Uji

Multikolinearitas

Sumber: Data

yang telah diolah

Tabel 6. Hasil

Uji

Heteroskedastisitas

Sumber: Data

yang diolah (2017) 


\subsection{Analisis Regresi Linier Berganda}

Penelitian ini menggunakan analisis linear berganda dengan tingkat signifikan sebesar 5\%

JURNAL

MANAJEMEN

INDONESIA

\section{Vol.17 No.3}

Desember 2017

Tabel 7.

Rangkuman Uji

Regresi Liniear

Berganda

Sumber: Data yang telah diolah (2017) $(\alpha=0,05)$ untuk menguji hipotesis diajukan. Hasil uji regresi liniear berganda dapat dilihat dalam tabel 7 sebagai berikut:

\begin{tabular}{|c|c|c|c|c|}
\hline Variabel & $\begin{array}{c}\text { B (Standardized } \\
\text { Coefficients) }\end{array}$ & $\mathbf{t}$ & Sig. $t$ & Keterangan \\
\hline Konstanta & 6.074 & 0.483 & 0.634 & \\
\hline $\mathrm{X} 1$ & 0.416 & 1.265 & 0.221 & \\
\hline $\mathrm{X} 2$ & 0.703 & 2.158 & 0.044 & \\
\hline R Square & .330 & & & \\
\hline Adjusted R Square & .260 & & & \\
\hline$F_{\text {hitung }}$ & 4.681 & & & \\
\hline $\mathrm{F}_{\text {tabel }}$ & 3,44 & & & \\
\hline Sig. & 0.022 & & & \\
\hline$t_{\text {tabel }}$ & 2,073 & & & \\
\hline
\end{tabular}

Persamaan regresi linier berganda sebagai berikut:

$$
\gamma^{\prime}=6.074+0.416 X_{1}+0.703 X_{2}
$$

Interpretasi dari uji regresi liniear berganda menyebutkan bahwa nilai konstanta a diperoleh sebesar 6.074. Disamping itu koefisen regresi lingkungan kerja fisik sebesar 0.416 dan non-fisik sebesar 0.703 maka dari itu jika variabel independen lain nilainya tetap serta variabel independen yang diujikan mengalami kenaikan $1 \%$, maka variabel dependen akan mengalami peningkatan sebesar 0,416 dan 0,703. Dalam uji koefisien determinasi kontribusi lingkungan kerja pada kinerja karyawan sebesar 26\%, sedangkan sisanya sebesar $74 \%$ dipengaruhi atau dijelaskan oleh variabel lainnya dan tidak dimasukkan dalam pelaksanaan penelitian. Dari hasil Coefficients Beta didapatkan variabel yang memiliki nilai regresi yang paling besar dan memiliki dominasi terhadap kinerja karyawan. Mengacu pada Tabel 7, hasil dari uji hipotesis dibuktikan melalui perbandingan thitung dan ttabel, dilihat kaidah pengujian secara parsial bahwa thitung lebih kecil dari ttabel $(1.265<2,073)$, maka tidak terdapat pengaruh yang signifikan antara lingkungan kerja fisik pada kinerja karyawan, sedangkan kaidah pengujian lingkungan kerja non fisik menunjukkan thitung > ttabel, $(2.158>2,073)$ sehingga lingkungan kerja non fisik memiliki pengaruh yang signifikan pada kinerja karyawan. Selanjutnya secara simultan ditunjukan dengan cara membandingkan antara Fhitung > Ftabel hasilnya Fhitung > Ftabel $(4.68>3,44)$ artinya terdapat pengaruh secara signifikan antara lingkungan kerja fisik dan non fisik secara bersama-sama pada kinerja karyawan, Dari hasil tersebut lingkungan kerja non-fisik memiliki pengaruh yang paling tinggi/ dominan terhadap kinerja karyawan dengan memiliki nilai standar koefisien beta sebesar 0,703.

Lingkungan kerja dalam tatanan organisasi perusahaan sangatlah fundamental agar lebih diperhatikan oleh para stakeholder. Sebagai pimpinan yang baik dalam mengelola manajemen perusahaan perlu adanya upaya untuk meningkatkan kontribusi dari lingkungan kerja, meskipun lingkungan kerja tidak secara holistik bersentuhan langsung dalam operasional perusahaan namun lingkungan kerja memiliki kapabilitas tersendiri dalam memberikan pengaruh langsung kepada karyawan yang melaksanakan proses produksi. Bagi para stakeholder dan divisi human 
resource development (HRD) terkait dengan kinerja karyawan yang selalu tidak konsiten, perlu memberikan perhatian dan kepedulian akan terciptanya lingkungan kerja yang menjadi generator motivasi bagi terbentuknya kinerja karyawan. Perusahaan yang memiliki kepedulian akan lingkungan kerja akan senantiasa mengadaptasikan upaya pengoptimalan dalam penyediaan lingkungan kerja memadai sehingga menjadi daya dukung untuk terciptanya keberhasilan dalam bisnis perusahaan.

Lingkungan kerja dapat dijadikan sebagai wahana dimana para karyawan melakukan aktivitas pengorbanan tenaga, pikiran dan waktu untuk perusahaan. Lingkungan kerja yang mengacu pada ekspektasi perusahaan profesional akan membuat karyawan merasa senang, aman dan nyaman dalam melakukan pekerjaannya sehingga memungkinkan memacu para karyawannya bekerja secara optimal, pekerjaan yang dilakukan secara optimal akan menjadikan pencapaian dari target perusahaan tercapai secara efektif dan efisien. Karyawan dapat fokus dalam melakukan pekerjaanya akibat dari lingkungan kerja yang sesuai dengan ekspektasi dan dapat mendongkrak kinerja karyawan. Jika karyawan menyukai lingkungan kerja tempat karyawan bekerja, maka karyawan tersebut akan nyaman di tempat kerjanya untuk melakukan aktivitas sehingga waktu kerja dipergunakan secara efektif dan optimalisasi kinerja karyawan juga tinggi.

Pengujian koefisen regresi dihasilkan bahwa adanya nilai positif yang ditimbulkan dari aksesibilitas lingkungan kerja yang mudah diakses atau didapatkan diperusahaan sehingga memberikan kenyamanan tersendiri dan berimplikasi pada kinerja karyawan. Selain itu juga hasil dari koefisen determinasi dapat dibuktikan bahwa masih besarnya pengaruh dari faktor lain terhadap kinerja karyawan yang tidak diujikan dalam penelitian ini sedangkan keberpengaruhan faktor lingkungan kerja hanya sebesar 26\%. Dalam dominasi antara variabel independen kepada variabel dependen didapatkan bahwa lingkungan kerja non fisik mendominasi keberpengaruhan dalam meningkatkan kinerja karyawan perusahaan.

Hasil uji hipotesis menujukkan lingkungan kerja fisik tidak berpengaruh signifikan pada kinerja karyawan dari hasil temuan tersebut dapat diinterprestasikan bahwa karyawan BPR Syariah Al-Madinah tidak terlalu mempersoalkan lingkungan yang berkaitan dengan fisik justru karyawan tersebut menggap bahwa hubungan, harmonisasi dan komunikasi dalam organisasi perusahaan sangat diutamakan untuk meningkatkan kinerja pada karyawan, hal tersebut dapat dibuktikan bahwa lingkungan kerja non fisik secara parsial berpengaruh pada kinerja karyawan. Disamping itu juga ternyata secara simultan kinerja karyawan dipengaruhi secara signifikan oleh lingkungan kerja, maka alangkah lebih baiknya lingkungan kerja secara fisik maupun non fisik dapat bersinergi pada perusahaan untuk menunjang pencapaian kinerja karyawan yang produktif sesuai ekspektasi dan target perusahaan dimasa mendatang

\section{$5 \quad$ Kesimpulan dan Saran}

Berdasarkan hasil analisis yang telah dilakukan, dapat disimpulkan bahwa terdapat hubungan positif antara lingkungan kerja fisik dan lingkungan kerja non-fisik pada kinerja karyawan. Secara terpisah, lingkungan kerja fisik tidak memiliki kontribusi secara signifikan pada kinerja karyawan, sedangkan lingkungan kerja non-fisik berkontribusi secara signifikan pada kinerja karyawan. Maka dari itu semakin baik lingkungan kerja yang diciptakan maka akan berimplikasi pada peningkatan kinerja karyawan BPR Syariah Al-Madinah Kota Tasikmalaya.

Secara simultan, penelitian ini menunjukkan bahwa lingkungan kerja yang terdiri dari lingkungan fisik dan lingkungan non-fisik berpengaruh signifikan pada kinerja karyawan dari hal tersebut membuktikan bahwa di antara kedua kondisi lingkungan kerja, dapat memberikan kontribusi yang positif pada perkembangan kinerja karyawan.

Saran kepada perusahaan berdasarkan hasil yang diperoleh, maka usaha perusahaan untuk melengkapi sarana dan prasarana merupakan kewajiban dari setiap perusahaan, dimana perusahaan wajib menciptakan lingkungan kerja yang representatif merupakan cerminan perusahaan yang profesional. Untuk memberikan kenyaman dan keamanan pada karyawan dalam melakukan pekerjaannya. Ekspektasi karyawan terhadap perusahaan tempatnya bekerja 
sangat tinggi dimana dapat ditunjukkan perusahaan dengan menciptakan lingkungan kerja yang kondusif diibaratkan seperti memberikan pelayanan kepada karyawan, dan begitu juga sebaliknya karyawan akan memberikan loyalitasnya kepada perusahaan jika ekspektasinya terpenuhi.

\section{JURNAL}

\section{MANAJEMEN}

INDONESIA

\section{Vol.17 No.3}

Desember 2017

\section{Daftar Pustaka}

Becker, F. D. (1985). Quality of work environment (QWE): Effects on office workers. Journal of Prevention \& Intervention in the Community, 4(1-2), 35-57.

De Cenzo, D. A., \& Robbins, S. P. (1996). Human resource management. John Wiley\& Sons. Inc. Newyork.

Ganapathi, R., \& Prasad, M. B. (2008). Effects of working environment on the performance of executives. Asia Pacific Business Review, 4(3), 117-123.

Ghozali, I. (2011). Aplikasi Analisis Multivariate dengan program IBM SPSS 19 (edisi kelima). Semarang: Universitas Dipenegoro.

Keputusan Menteri Kesehatan RI No 1405/MENKES/SK/XI/2002 tentang Persyaratan Kesehatan Lingkungan Kerja Perkantoran dan Industri.

LAN (Lembaga Administrasi Negara) RI. (1992). Budaya Organisasi dan. Peningkatan Kinerja. Bandung: CV Mandar Maju.

Mangkunegara, A. A. P. (2004). Manajemen Sumber Daya Manusia. PT. Remaja Rsodakarya, Bandung.

Masri, S., \& Effendi, S. (2006). Metode Penelitian Survei. Jakarta: LP3ES.

Nitisemito, A. S. (2002). Manajemen Personalia Edisi Revisi. Jakarta: Ghalia Indonesia.

Priyatno, D. (2013). Analisis korelasi, regresi dan multivariate dengan SPSS. Yogyakarta: Gava Media.

Siagian, S. P. (2002). Kepemimpinan Organisasi \& Perilaku Administrasi. Jakarta: Penerbit Gunung Agung.

Simanjuntak, P. J. (2003). Produktivitas Kerja Pengertian dan Ruang Lingkupnya. Jakarta: Prisma.

Smith, A. W. (1982). Philosophy of Education. New York: Harper \& Row.

Sugiyono. (2010). Metode Penelitian Kuantitatif, Kualitatif \& RND. Bandung: Alfabeta.

Sutrisno, E. (2010). Manajemen Sumber Daya Manusia. Jakarta: Kencana Prenada Media Group.

Werther, W. B., \& Davis, K. (1996). Human Resource and Personnel Management. Edisi 5. USA: McGraw Hill.

Jurnal Manajemen Indonesia 